\title{
PENURUNAN KADAR FOSFAT DALAM LIMBAH CAIR RUMAH SAKIT X DENGAN MENGGUNAKAN TANAMAN AIR KAYU APU (PISTIA STRATIOTES) TAHUN 2015
}

\author{
Isnia Fitri Abdillah, Suprijandani, Fitri Rohkmalia
}

\begin{abstract}
Hospital liquid waste are all waste water including faeces derived form hospital activities. Hospitals location used to be far from settlements, now they are generally in the middle of dense residential areas, which trigger pollution problem. Pollution problem of liquid waste often trigger conflicts between hospital and community living around it. One of the harmfull pollutant compounds is phosphate. This study aim to determine water lettuce effectiveness in reducing phosphate levels.

This research was categorized as actual experimental research with "Pretest and Posttest Design with Controlled Group". Data was obtained from secondary and primary data. 20 liters sample was used for 3 times experiment of 15 days process. Data were than analyzed by using ANOVA test.

Results shows reduction of phosphate level after treatment with water lettuce ( $p=$ $0.000<0.05)$. $L S D$ results showed that there was difference in phosphate level reduction on 5 days, 10 days, 15 days treatment $(p=0.000<0.05)$. Phosphate level did not exceed Threshold Limit Value (TLV) stipulated in East Java Governor Regulation No. 72 in 2013.

Related institutions (hospitals with the liquid waste quality that has not meet the requirements) are suggested make pool and plants arrangement inside it. The pool is then filled with liquid waste from outlet. Water quality of liquid waste should be improved prior to flowing it to city.
\end{abstract}

Keywords: phosphate, water lettuce, hospital liquid waste

\section{PENDAHULUAN}

Sejalan dengan perkembangan penduduk yang sangat pesat, lokasi RS yang dulunya jauh dari daerah pemukiman penduduk, sekarang berada di tengah pemukiman penduduk yang cukup padat, sehingga masalah pencemaran akibat limbah cair RS sering menjadi konflik antara pihak RS dengan masyarakat (Dalimartha $\mathrm{dkk}$, 2010).

Salah satu senyawa pencemar yang berbahaya adalah fosfat. Pada Peraturan Gubernur Jawa Timur No. 72 Tahun 2013 tentang baku mutu air limbah bagi usaha dan/atau kegiatan RS, telah mempersyaratkan kandungan fosfat sebesar $2 \mathrm{mg} / \mathrm{lt}$.

Berdasarkan paparan diatas tujuan penelitian ini adalah untuk mengetahui efektifitas tanaman kayu apu dalam menurunkan kadar fosfat dalam limbah cair RS.

\section{METODE PENELITIAN}

Penelitian ini termasuk penelitian eksperimen sungguhan yang bertujuan mengetahui kemampuan tanaman kayu apu dalam menurunkan kadar fosfat dalam limbah cair (Notoatmodjo, 2011).

Dalam penelitian ini yang menjadi populasi adalah limbah cair RS $X$. Sampel yang diambil adalah sebanyak 80 liter.Selanjutnya ditampung dalam bak reactor yang dibagi menjadi 1 bak kontrol, 3bak percobaan.

\section{HASIL PENELITIAN DAN PEMBAHASAN}

Hasil pengukuran $\mathrm{pH}$ dan suhu limbah cair selama proses penelitian yang berlangsung 15 hari yaitu 7 dan suhu berkisar antara $26-$ $27^{\circ} \mathrm{C}$. Hasil penurunan kadar fosfat sebagai berikut:

Tabel 1

Hasil Pengukuran Kadar Fosfat

\begin{tabular}{llllll}
\hline No. & Bak Reaktor & $\begin{array}{l}\text { Kadar Awal } \\
(\mathbf{m g} / \mathbf{l t})\end{array}$ & $\begin{array}{l}\text { Hari ke- } \\
\mathbf{5}\end{array}$ & $\begin{array}{l}\text { Hari } \\
\mathbf{1 0}\end{array}$ & $\begin{array}{l}\text { ke- } \\
\mathbf{1 5}\end{array}$ \\
\hline 1. & Bak Percobaan 1 & 7.7 & 6.42 & 3.263 & 1.587 \\
\hline 2. & Bak Percobaan 2 & 7.7 & 6.76 & 3.204 & 1.539 \\
\hline 3. & Bak Percobaan 3 & 7.7 & 6.92 & 3.109 & 1.179 \\
\hline 4. & Bak Kontrol & 7.7 & 7.7 & 6.488 & 6.239 \\
\hline Sumber: Data Primer (2015) & & & &
\end{tabular}


Berdasarkan tabel 1 dapat dilihat hasil pengamatan selama 15 hari, didapatkan hasil sebelum tumbuhan kayu apu ditanam di bak reaktor masih tampak segar. Pada hari ke-5 mulai tampak daun yang dalam bak reaktor yang berisi air limbah, tanaman kayu apu tampak menguning, yaitu tanaman pada Bak Percobaan 1 dan 3 tetapi terlihat mulai tumbuh

kuncup baru. Hari ke-enam mulai layu dan daunnya rontok.Pada hari ke-enam tanaman Bak Percobaan 2 mengalami hal yang sama seperti pada Bak Percobaan 1 dan 3. Pada hari - hari selanjutnya tanaman tumbuh subur. Hal ini menunjukkan bahwa tanaman dapat beradaptasi dengan limbah cair yang ada dalam Bak Percobaan.

\section{Analisa Hasil Pengukuran pH}

Selama proses penelitian dilakukan pengukuran $\mathrm{pH}$ setiap harinya. Dari hasil pengukuran diketahui bahwa $\mathrm{pH}$ limbah cair sudah optimal yaitu sebesar 7 dimana menurut (Salisbury et al.,2011) Penelitian Ginting (2012) yang menjelaskan tanaman dapat menyerap unsur hara. Hal ini sesuai dengan $\mathrm{pH}$ yang diperkenankan. Adapun rentang $\mathrm{pH}$ yang diperlukan tanaman Kayu Apu untuk dapat tumbuh dengan baik yaitu pada pH 6-7 (Tjitrosomo, 2010).

\section{Analisa Hasil Pengukuran Suhu}

Hasil pengukuran suhu pada penelitian ini yaitu antara $26-28^{\circ} \mathrm{C}$. Peningkatan dan penurunan suhu dapat disebabkan oleh morfologi tanaman. Tanaman kayu apu memiliki bentuk morfologi yang menutupi seluruh permukaan media sehingga dapat mempengaruhi nilai suhu pada media (Hermawati dkk, 2013).

Kondisi suhu sebesar $26-28^{\circ} \mathrm{C}$ masih sesuai untuk pertumbuhan Kayu apu dikarenakan suhu untuk pertumbuhan Kayu Apu berkisar antara $22-30^{\circ} \mathrm{C}$ (Sari et al., 2014)

\section{Analisa Pengukuran Kadar Fosfat}

Berdasarkan tabel 1 diketahui bahwa terjadi penurunan kadar fosfat dalam limbah cair. Kadar fosfat sebelumnya sebesar 7,7. Hari ke 5 mengalami penurunan sebesar $16.62 \%$ pada Bak Percobaan 1, Bak Percobaan 2 sebesar $12.21 \%$, dan $10.13 \%$ pada Bak Percobaan 3. Setelah 10 hari menurun sebesar $57.62 \%$ pada Bak Percobaan 1, Bak Percobaan 2 sebesar $58.38 \%$, dan 59.62\% Bak Percobaan 3. Pada hari ke 15 menurun sebesar $79.39 \%$ pada Bak Percobaan 1, Bak Percobaan 2 sebesar $80.01 \%$, dan $84.69 \%$ Bak Percobaan 3.
Penurunan kadar fosfat dapat disebabkan oleh akar yang berperan baik dalam menyerap fosfat. Penyerapan fosfat oleh akar tergantung pada sistem tranpor aktif dalam membran sel dan melibatkan adenosin trifosfat (ATP) sehingga mampu melawan konsentrasi fosfat dalam sel akar (Hermawati dkk. 2013).

Kandungan fosfat dalam jumlah yang berlebihan pertumbuhan akar akan lebih tajuk (Hanum, 2010).

Dari uji anova,didapatkan hasil $(p=0.000<0.05)$ ada perbedaan antara kadar fosfat sebelum dan setelah diaplikasikan dengan kayu apu antara selama 5 hari, 10 hari, dan 15 hari. Dari hasil uji LSD didapatkan hasil $\mathrm{p}=0.000<0.05$ yang berarti bahwa ada perbedaan penurunan kadar fosfat antara lama perlakuan 5 hari, 10 hari, 15 hari. Hal ini karena semakin lama tanaman dikontakkan dengan limbah cair maka semakin lama daya serap akar tanaman yang ditandai dengan pertumbuhan akar tanaman.Pertumbuhan tanaman menjadi lebih banyak tumbuh kuncup baru. Dengan demikian air limbah yang mengandung fosfat dapat mempengaruhi pertumbuhan tanaman kayu apu dan kadar fosfat dapat diturunkan dengan menggunakan tanaman ini.

Jadi kadar fosfat akhir pada hari ke 15 adalah sebesar 1.587 mg/lt pada Bak Percobaan 1, pada Bak Percobaan 2 sebesar $1.539 \mathrm{mg} / \mathrm{lt}$, dan $1.179 \mathrm{mg} / \mathrm{lt}$ pada Bak Percobaan 3.Jumlah kadar fosfat tersebut memenuhi persyaratan baku mutu Peraturan Gubernur Jawa Timur No. 72 Tahun 2013.

\section{KESIMPULAN}

1. Kadar fosfat dalam limbah cair sebanyak 20 liter dan diberi perlakuan dengan tanaman kayu apu sebanyak 8 tanaman pada masing - masing Bak Percobaan menurun di hari ke- 5 pada Bak Percobaan 1 sebesar $16.62 \%$, Bak Percobaan 2 sebesar 12.21\%, dan $10.13 \%$ Bak Percobaan 3. Setelah 10 hari menurun sebesar $57.62 \%$ pada Bak Percobaan 1, Bak Percobaan 2 sebesar $58.38 \%$, dan $59.62 \%$ Bak Percobaan 3. Hari ke 15 mengalami penurunan sebesar 79.39\% pada Bak Percobaan 1, Bak Percobaan 2 sebesar $80.01 \%$, dan $84.69 \%$ Bak Percobaan 3.

2. Hasil Pengukuran Kadar Fosfat yang telah dilakukan uji Anova didapatkan hasil $p=$ $0.000<0.05$ yang berarti bahwa ada penurunan kadar fosfat selama 5 hari, 10 hari, dan 15 hari. Dari hasil uji LSD didapatkan hasil ada perbedaan 
penurunan kadar fosfat antara lama perlakuan 5 hari, 10 hari, dan 15 hari. Berdasarkan Peraturan Gubernur Jawa Timur No. 72 Tahun 2013 tentang baku mutu air limbah bagi usaha dan/atau kegiatan RS, mempersyaratkan kadar fosfat dalam limbah cair RS adalah 2 $\mathrm{mg} / \mathrm{Itdan}$ kadar fosfat terakhir pada hari ke- 15 sebesar $1.587 \mathrm{mg} / \mathrm{lt}$ pada Bak Percobaan 1, Bak Percobaan 2 sebesar $1.539 \mathrm{mg} / \mathrm{lt}$, dan $1.179 \mathrm{mg} / \mathrm{lt}$ Bak Percobaan 3, jumlah kadar fosfat tersebut memenuhi persyaratan.

3. Tanaman kayu apu dapat memperbaiki kualitas air limbah.

\section{SARAN}

Bagi instansi (RS yang mengalami masalah pada kualitas limbah cairnya yang masih belum sesuai persyaratan) dapat membuat kolam-kolam dan penataan tanaman dalam kolam tersebut untuk selanjutnya kolam tersebut diisi dengan air limbah dari outlet dan dilakukan perbaikan kualitas air limbahnya sebelum air limbah dialirkan ke aliran kota.

\section{DAFTAR PUSTAKA}

Dalimartha, Setiawan. 2010. Atlas Tumbuhan Obat Indonesia Jilid 4. Jakarta, Puspa Swara Anggota IKAPI.

Ginting Perdana, 2012. Sistem Pengelolaan Lingkungan dan Limbah Industri,Bandung: CV. Yrama Widya.

Hanum, 2010. Teknik Budidaya Tanaman Jilid 1. Direktorat Pembinaan Sekolah Menengah Kejuruan. Jakarta.
Hermawati, Ervina., Wiryanto., Solichatun. 2013. Fitoremediasi Limbah Detergen Menggunakan Kayu Apu (Pistia stratiotes L.) dan Genjer (Limnocharis flava L.). Surakarta, Universitas Sebelas Maret : Jurusan Biologi FMIPA. biosmart.mipa.uns.ac.id/ind ex.php/biosmart/article/download/9 /10 diakses pada tanggal 12 Januari 2015 pukul 14.17 WIB.

Notoatmodjo, Soekidjo, 2011. Kesehatan Masyarakat. Jakarta, Rineka Cipta. Cetakan kedua

Peraturan Gubernur Jawa Timur Nomor 72 Tahun 2013 Tentang Baku Mutu Air Limbah Bagi Industri Dan/Atau Kegiatan Usaha Lainnya.

Salisbury, F.B. and C.W. Ross. 2011.Fisiologi Tumbuhan. ITB, Bandung.

Sari, Lutfiana I.,dkk. 2014. Kemampuan Eceng Gondok (Eichhornia Sp.), Kangkung Air (Ipomea Sp.), dan Kayu Apu (Pistia Sp.) dalam Menurunkan Bahan Organik Limbah Industri Tahu (Skala Laboratorium). Semarang. Universitas Diponegoro : Program Studi Manajemen Sumberdaya Perairan, Jurusan Perikanan Fakultas Perikanan dan Ilmu

Kelautan.eprints. undip.ac.id/view/t ype/thesis. default.htm/ diakses pada tanggal 15 Januari 2015 pada pukul 13.15 WIB.

Tjitrosomo, S. S., S. Harran, M. Djaelani dan A. Sudiarto. 2010. Botani umum.Jilid 2. Departemen Botani. Institut Pertanian Bogor. Bogor 